\title{
Cytotoxicity of Mycobacterium indicus pranii on Mia-Pa-Ca2 cells
}

\author{
A. Darji ${ }^{1}$, N. Desai ${ }^{1}$, R. Modi ${ }^{2}$, B. Khamar ${ }^{2}$ and S. Rajkumar ${ }^{3 *}$
}

\begin{abstract}
Background: MIP is a cultivable, non-pathogenic organism, which shares several antigens with Mycobacterium tuberculosis and Mycobacterium leprae. It has several proposed clinical applications. However, its cytotoxic effect on pancreatic cancer has not been documented. Hence, the study was conducted to investigate MIP induced cytotoxicity on Mia-Pa-Ca2 cells. To determine the cytotoxic potential of heat killed Mycobacterium indicus pranii (MIP) on pancreatic cancer cells in vitro along with gemcitabine \& 5-fluorouracil (5-FU). Mitogen-activated protein kinase (MAPK) level was also studied post MIP treatment.

Methods: Cytotoxic effect of MIP, gemcitabine and 5-FU on Mia-Pa-Ca2 cells was determined. We have analyzed extent of apoptosis using flow cytometry and changes in p38 levels, c-Jun N-terminal kinases (JNK) and extracellular signal-regulated kinase (ERK) using ELISA.

Results: MIP not only exhibits cell cytotoxicity in dose dependent manner, but also enhances efficacy of gemcitabine and 5-FU when used in combination. Flow cytometry analyses reveals apoptosis of Mia-Pa-Ca2 cells post MIP treatment compared to untreated cells. MAPK pathway study using ELISA shows that p38 and JNK levels are suppressed while there is no change in ERK level.
\end{abstract}

Conclusion: With these results we conclude that MIP is a cytotoxic agent. Cytotoxicity is exhibited by apoptosis. Combining MIP with gemcitabine and 5-FU shows synergistic effect.

Keywords: 5- fluorouracil, Gemcitabine, Mia-Pa-Ca2 cells, Mitogen activated protein kinase (MAPK), Mycobacterium indicus pranii (MIP), Pancreatic cancer

\section{Background}

Pancreatic cancer is the twelfth most common cancer in the world along with kidney cancer [1]. It is also the seventh most common cause of death among all cancers. In 2012, 338,000 pancreatic cancer cases and 331,000 deaths were reported all over the world which accounted for $2.4 \%$ of all cancer cases [1]. It is estimated that 53,670 new cases will be diagnosed and 43,090 people will die in 2017 in US. In the western world, it is the fourth common cause of cancer related death among men and women and is expected to be one of the most dangerous cancer in next decade [2].

Lack of diagnosis at an early stage is the major factor for high prevalence of pancreatic cancer. As a result most cancers are already metastasized by the time they

\footnotetext{
* Correspondence: shalini.rjk@nirmauni.ac.in

${ }^{3}$ Institute of Science, Nirma University, Ahmedabad, Gujarat 382481, India Full list of author information is available at the end of the article
}

are diagnosed. Although gemcitabine has been the preferred treatment for pancreatic cancer, various types of combination chemotherapy have been used to increase the response rate, especially in patients with metastatic pancreatic cancer, such as nab-paclitaxel with gemcitabine, or FOLFIRINOX (5-fluorouracil, leucovorin, irinotecan, and oxaliplatin), with/without gemcitabine [3]. Patients who undergo resection still only have a median survival of 14-20 months and a 5 -year survival rate of $10 \%$ with surgery alone and up to $25 \%$ with adjuvant chemotherapy [4]. However, chemotherapy may induce serious adverse effects hence rather than single agent chemotherapy, combination chemotherapy has become a new alternative in patients with advanced pancreatic cancer, with an increased survival benefit [5].

Experimental cancer treatments are medical therapies intended or claimed to treat cancer by improving, 
supplementing or replacing conventional methods. These include nanoparticles, photodynamic therapy, gene therapy, complementary and alternative therapy, COBALT (COmbination BActerioLytic Therapy) and bacterial treatment $[6,7]$. The role of bacteria as an anti-cancer agent was accidentally developed almost a century ago and is famously known as "Coley's toxin" [8]. Following these discoveries, several other bacterial species have been found to elicit significant anti-tumour activity in both in vitro and in vivo systems such as Salmonella, Diphtheria, Pseudomonas, Clostridium [6, 9]. Bacterial therapies have an advantage over passive drug molecules because they can actively target intratumoral microenvironments with preferential growth and active motile transport. Recent advances in engineered therapeutic delivery include temporal control of cytotoxin release, enzymatic activation of pro-drugs, and secretion of physiologically active biomolecules [10].

In recent studies, use of mycobacterial agents like Mycobacterium vaccae (SRL172) has been shown to be effective in the treatment of adenocarcinoma of the lung and renal cell cancer. The M. vaccae-induced apoptosis appears to be most effective against multiple carcinomas, due to immune regulation, as reflected in the selective enhancement of Type $1 \mathrm{~T}$ helper (Th1) and down-regulation of Type $2 \mathrm{~T}$ helper (Th2) cell mediated immune response [11].

Mycobacterium indicus pranii (MIP) is a cultivable, non-pathogenic organism, which shares several antigens with $M$. tuberculosis and M. leprae [12, 13]. MIP, previously known as Mw (Mycobacterium w), a saprophytic bacterium has been shown to stimulate cell mediated immune responses in leprosy patients [13, 14]. Intradermal (ID) injection of MIP at the dose of $1 \times 10^{7}$ cells $/ \mathrm{ml}$ along with chemotherapy resulted in greater reduction in the bacterial load in lungs and other organs of Tuberculosis (TB) infected animals [12]. Injecting MIP intradermally in the deltoid region at $5 \times 10^{8}$ cells per dose for leprosy patients shortens the duration of drug treatment [15]. Interestingly, heat killed MIP is a potent Toll-like receptors (TLR) 2 agonist, which stimulates macrophage activation [16] and induces potent Th1 response [17]. Despite these observations, the mechanism by which MIP elicits an apoptotic response in pancreatic cancer is not known.

Hence, the present study was undertaken to investigate the cytotoxic effect of heat killed MIP and standard available chemotherapeutic drugs (gemcitabine and 5-flurouracil) on a human pancreatic carcinoma cell line, Mia-Pa-Ca2. A second aim was to examine the contribution of the MAP kinases (existence and activation) in apoptosis of Mia-Pa-Ca2 cells after stimulating with MIP.

\section{Methods}

\section{Cell lines and culture medium}

The human pancreatic cancer cells Mia-Pa-Ca2 were obtained from American Type Culture Collection, Rockville, MD. Mia-Pa-Ca2 cells were maintained in DMEM (Dulbecco's modified Eagle's Medium); Sigma Aldrich supplemented with $10 \%(v / v)$ FBS (Fetal bovine serum); Gibco, $2 \mathrm{mM}$ L-glutamine and $2 \mathrm{mM}$ penicillin/ streptomycin. Cell lines were incubated in a humidified atmosphere with $5 \% \mathrm{CO}_{2}$ at $37^{\circ} \mathrm{C}$.

\section{Chemicals and reagents}

Gemcitabine (gemcitabine hydrochloride) -Tabicad (1000 mg), 5- fluorouracil (5-FU) - Florac $\left(50 \mathrm{mg} \mathrm{ml}^{-1}\right)$ and MIP were sourced from Cadila pharmaceuticals Ltd. Tabicad was reconstituted in $0.9 \%(w / v)$ saline solution to a $200 \mathrm{mM}$ stock solution and stored at room temperature.

\section{Mycobacterium indicus pranii}

MIP cells were incubated at $37^{\circ} \mathrm{C}, 80 \mathrm{rpm}$ for 6 to 8 days in a shaker incubator. After incubation, cells were harvested at $6000 \mathrm{~g}$ for $60 \mathrm{~min}$ and cell pellet was retained. After two washes with suspension buffer $\left(9 \mathrm{~g} \mathrm{NaCl} \mathrm{l}^{-1}\right.$, $2 \mathrm{~g}$ Tween $80 \mathrm{l}^{-1}$ ), cells were re-suspended in the same buffer as $1 \mathrm{~g}$ cells in $22.5 \mathrm{ml}$ of suspension buffer. Cells were inactivated by subjecting them to high pressure saturated steam at $123 \pm 2{ }^{\circ} \mathrm{C}$ [15 psi] for $30 \mathrm{~min}$. MIP cell suspension was stored at $2-8{ }^{\circ} \mathrm{C}$ for further use. The optical density (OD) of the suspension was measured spectrophotometerically at $600 \mathrm{~nm}$ which was extrapolated to cell count (OD 0.56 corresponded to $2.33 \times 10^{9} \mathrm{cell} \mathrm{ml}^{-1}$.

\section{Efficacy assessment of gemcitabine, 5-FU and MIP on Mia- $\mathrm{Pa}-\mathrm{Ca} 2$ cells}

To study the effect of gemcitabine, 5-FU and MIP on cell growth of Mia-Pa-Ca2 cells; the MTS (3-(4,5-dimethylthiazol-2-yl)-5-(3-carboxymethoxyphenyl)-2-(4sulfophenyl)-2H-tetrazolium) cell proliferation assay (CellTiter $96^{\circ}$ AQueous One Solution, Promega, Southampton, UK) was used. For assay, Mia-Pa-Ca2 cells were harvested with trypsin (Invitrogen) and plated in 96-well plates in complete DMEM media at a density of $1 \times 10^{4}$ cells/well. Gemcitabine (10 nM to $\left.320 \mathrm{nM}\right), 5$-FU $(1.56 \mu \mathrm{g}$ to $100 \mu \mathrm{g})$ and MIP $\left(1.5 \times 10^{5}\right.$ to $5 \times 10^{8} \mathrm{MIP}$ cells $\mathrm{ml}^{-1}$ ) were added to the wells so that the final volume per well was $100 \mu \mathrm{l}$ across the plate. Plates were incubated in a humidified atmosphere with $5 \% \mathrm{CO}_{2}$ at $37^{\circ} \mathrm{C}$ for $48 \mathrm{~h}$. Post incubation $20 \mu \mathrm{l}$ of CellTiter $96^{\circ}$ reagent was added to wells. Subsequently, the plates were again incubated at $37{ }^{\circ} \mathrm{C}$ for $1 \mathrm{~h}$ After $1 \mathrm{~h}$, plates were gently agitated and then OD was read at $490 \mathrm{~nm}$ with correction at $630 \mathrm{~nm}$ on a spectrophotometer. 
Efficacy of gemcitabine and 5-FU in combination with MIP Mia-Pa-Ca2 cells were plated at a density of $1 \times 10^{4}$ cells/ well in DMEM in 96-well plates. Cells were treated with variable- gemcitabine $(10 \mathrm{nM}$ to $320 \mathrm{nM})$ and 5 -FU $(1.56 \mu \mathrm{g}$ to $100 \mu \mathrm{g})$ separately in different set of experiments along with constant- MIP $\left(3 \times 10^{6} \mathrm{MIP}^{\circ}\right.$ cells $\left.\mathrm{ml}^{-1}\right)$. Cell survival was analyzed after $48 \mathrm{~h}$ at $37^{\circ} \mathrm{C}$, using the MTS assay as previously described. Briefly, synergism or antagonism for MIP plus gemcitabine or 5-FU was calculated by combination index (CI) using CompuSyn software program algorithm:

$$
\mathrm{CI}=\left[(\mathrm{D})_{1} /\left(\mathrm{D}_{\mathrm{x}}\right)_{1}\right]+\left[(\mathrm{D})_{2} /\left(\mathrm{D}_{\mathrm{x}}\right)_{2}\right]
$$

Where, $\mathbf{D}_{\mathbf{1}}$ is $50 \%$ inhibition of cell growth due to MIP.

$\mathbf{D}_{2}$ is either gemcitabine or $5 \mathrm{FU}$.

$\mathbf{D}_{\mathbf{x}}$ is the concentration of D1 or D2 that induce $50 \%$ inhibition of cell growth.

The CI values were calculated according to the method of Chou [18, 19] using CompuSyn software. Where, $\mathrm{CI}<1, \mathrm{CI}=1$ and $\mathrm{CI}>1$ indicate synergism, additive effect and antagonism, respectively.

\section{Apoptosis of Mia-Pa-Ca2 cells detected by Annexin V and Propidium iodide staining}

Post treatment with MIP, Mia-Pa-Ca2 cells were washed in cold DPBS (Dulbecco's phosphate-buffered saline), centrifuged and suspended in $1 \mathrm{X}$ annexin-binding buffer [prepared in accordance with the manufacturer's protocol (Cat\# V13242, Invitrogen, UK)] in such a way that the cell density was adjusted to $\sim 1 \times 10^{6} \mathrm{cells} \mathrm{ml}^{-1}$. A working solution of Propidium Iodide (PI) $\left(100 \mu \mathrm{g} \mathrm{ml}^{-1}\right)$ in $1 \mathrm{X}$ annexin-binding buffer was prepared. $5 \mu \mathrm{l}$ of FITC (Fluorescein isothiocyanate) annexin $\mathrm{V}$ (Component A) and $1 \mu \mathrm{l}$ of the $100 \mu \mathrm{g} \mathrm{PI} \mathrm{ml}{ }^{-1}$ working solution were added to each $100 \mu \mathrm{l}$ of cell suspension was incubated at room temperature for $15 \mathrm{~min}$. Following that $400 \mu \mathrm{l}$ of $1 \mathrm{X}$ annexin-binding buffer was added and the tube was gently tapped for mixing. The samples were kept on ice until analyzed. The stained cells were analyzed by flow cytometry, measuring the fluorescence emission at $530 \mathrm{~nm}$ or $575 \mathrm{~nm}$.

\section{Analysis of MAPK (p38, ERK \& JNK) by ELISA}

ELISA was performed using the commercially available kits [20] - Human/Mouse/Rat Phosho-p38 a (T180/ Y182) (R \& D Systems, Duoset IC), Human/Mouse/Rat Phosho-ERK 1/ERK2 (MultiScreen) and Human/Mouse/ Rat Phosho-JNK (Pan) (MultiScreen). Mia-Pa-Ca2 cells were cultured in $175 \mathrm{~cm}^{2}$ tissue culture flasks for $48 \mathrm{~h}$ before treatment. Cells were treated with MIP $\left(3.0 \times 10^{6}\right.$ and $1.25 \times 10^{8} \mathrm{MIP}$ cells ml${ }^{-1}$ ) for $48 \mathrm{~h}$. After treatment, $10^{6}$ cells were homogenized in lysis buffer containing protease and phosphatase inhibitors in accordance with the manufacturer's protocol (R\&D Systems). Briefly ELISA plates coated with antibody were used for the assay $[21,22]$. The plate were washed with $400 \mu \mathrm{l}$ wash buffer and blocked by adding blocking buffer. After blocking the plates were washed thrice, aspirated, tapped and dried. The strips for the respective MAPK were stored in a desiccator and the temperature was maintained at $2-8{ }^{\circ} \mathrm{C}$.

Moreover, MAPK standards for p38 $\alpha$ (78.125 to $5000 \mathrm{pg} \mathrm{ml}^{-1}$ ), ERK $1 \& 2$ (34.17 to $2187.5 \mathrm{pg} \mathrm{ml}^{-1}$ ) \& JNK $\left(221.25\right.$ to $\left.14,160 \mathrm{pg} \mathrm{ml}^{-1}\right)$ and samples were diluted as per manufacturer's protocol (R\&D Systems). The OD of each well was immediately determined at $450 \mathrm{~nm}$ using a spectral scanning multimode reader.

\section{Statistical analysis}

All tests were performed at least in triplicate and quantitative data are presented as Standard Deviation of mean. Graphical presentation was performed using commercial software Prism 5.0 (GraphPAD Software, CA). Results for cytotoxicity studies are displayed as \% of control. IC50 was calculated by an Excel add-in ED50V10 file.

\section{Results}

Effect of MIP, gemcitabine and 5-FU on Mia-Pa-Ca2 cells MIP exerted cytotoxic effect on Mia-Pa-Ca2 cells in vitro when used alone or in combination with chemotherapeutic drugs such as gemcitabine and 5-FU. Figure 1 shows that cell survival rate for Mia-Pa-Ca2 cells upon treatment with MIP decreased gradually till $6 \times 10^{7}$ MIP cells ml ${ }^{-1}$ and IC50 value was $3 \times 10^{6} \mathrm{MIP}$ cells $\mathrm{ml}^{-1}$. The IC50 values for gemcitabine which is the standard of care for pancreatic cancer was around $160 \mathrm{nM}$ (Table 1) while IC50 value for 5-FU was around $3.12 \mu \mathrm{g}$ (Table 2). On combining MIP at its IC50 value of $3 \times 10^{6}$ cells ml $^{-1}$ with gemcitabine, the IC50 value dropped 4 fold to $40 \mathrm{nM}$ (Table 1) and with 5-FU, the IC50 value dropped 2 fold to $1.562 \mu \mathrm{g}$ (Table 2). Both these data suggested that heat killed MIP can be used to lower the required doses of chemotherapeutic drugs.

\section{Cell morphology and apoptosis}

Cell morphology was analyzed by the conventional FACS (Fluorescence-activated cell sorting) staining Annexin VFLUOS and PI. Forward and side scatter showed population of MIP treated Mia-Pa-Ca2 cells appearing larger in size and more granular (Fig. 2a). This indicates apoptotic morphology in both early and late phase. Additionally, staining with PI showed clear shift of peak and more than $95 \%$ cells were dead which suggested that they were at early apoptotic phase (Fig. 2b). 


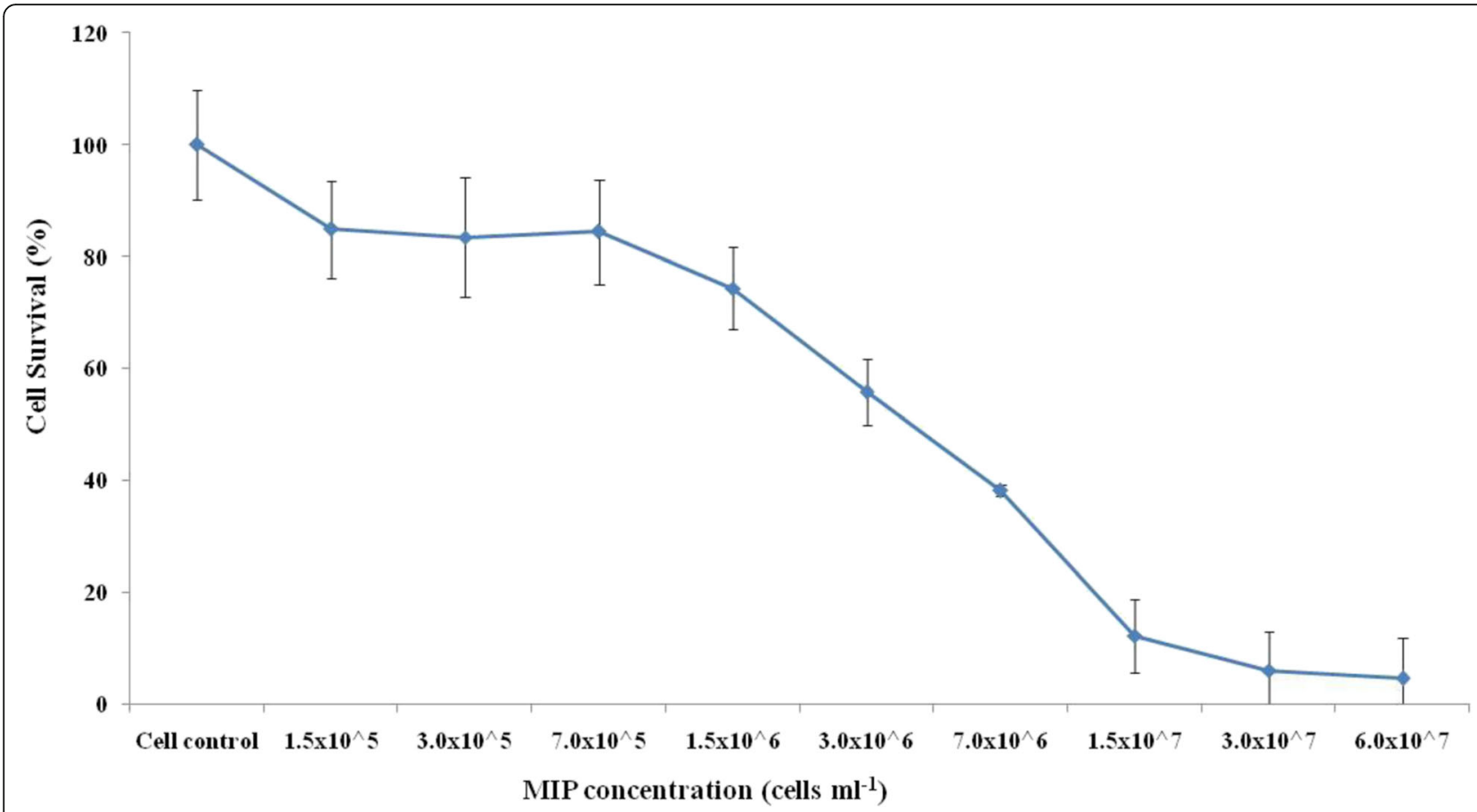

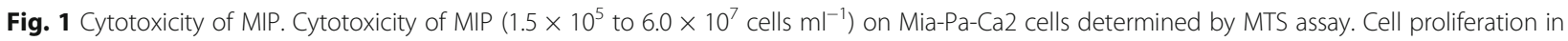
vitro was plotted as cell survival at indicated concentrations of these three compounds. Error bars indicate Mean \pm SD. Each plot is representative of four independent experiments

\section{MAPK level post treatment with MIP}

In order to further understand the mechanism behind apoptosis, we explored the change in MAPK (p38, JNK, ERK) level in Mia-Pa-Ca2 cells after treatment with MIP. When highest concentration of MIP was used i.e. $1.25 \times 10^{8}$ MIP cells $\mathrm{ml}^{-1}$, p38 levels decreased until $16 \mathrm{~h}$ with respect to control. After $16 \mathrm{~h}$, p38 levels started to increase and became almost equivalent to control at $48 \mathrm{~h}$. MIP cells at a concentration of $3.0 \times 10^{6}$ cells ml $\mathrm{ml}^{-1}$ resulted in down-regulation of p38 levels as compared to control (Table 3). Treatment with MIP cells at a concentration of $3.0 \times 10^{6}$ cells ml $^{-1}$ resulted in increase of JNK level (192 $\left.\mathrm{pg} \mathrm{ml}^{-1}\right) 16 \mathrm{~h}$ onwards. At all concentrations of MIP used, the JNK levels showed maximum downregulation with respect to control till $8 \mathrm{~h}$ (data not shown) after which levels increased again till $48 \mathrm{~h}$ (Table 3). Data

Table 1 Cytotoxicity of MIP $\left(3 \times 10^{6}\right.$ cells $\left.\mathrm{ml}^{-1}\right)$ in combination with gemcitabine (10 nM to $320 \mathrm{nM}$ ), in pancreatic cancer cells by MTS assay

\begin{tabular}{llllll}
\hline & \multicolumn{6}{l}{ Gemcitabine concentration $(\mathrm{nM})$} \\
\cline { 2 - 5 } & 0 & 40 & 80 & 160 & 320 \\
\hline Gemcitabine & 100 & 76 & 64 & 49 & 23 \\
Gemcitabine $+3 \times 10^{6} \mathrm{MIP}$ & 55 & 49 & 30 & 29 & 14 \\
$3 \times 10^{6} \mathrm{MIP}$ & 55 & - & - & - & - \\
\hline
\end{tabular}

Cell proliferation in vitro was plotted as cell survival (\%) at indicated concentrations of these two compounds. Each data point is the average of at least four determinations also indicated that with highest concentration of MIP i.e. $1.25 \times 10^{8}$ cells $\mathrm{ml}^{-1}$, ERK levels increased till $2 \mathrm{~h}$ and then decreased, upto $8 \mathrm{~h}$ (data not shown) after which the levels increased upto $48 \mathrm{~h}$. MIP cells at a concentration of $3.0 \times 10^{6}$ cells $\mathrm{ml}^{-1}$ resulted in decline of ERK levels with respect to control and reached a minimum value (223 $\mathrm{pg} \mathrm{ml}^{-1}$ ) at $2 \mathrm{~h}$ (data not shown) and then the levels increased $\left(273 \mathrm{pg} \mathrm{ml}^{-1}\right)$ till $48 \mathrm{~h}$. At all concentrations of MIP used, the ERK levels were changed throughout the period of study (Table 3). From this study, it can be concluded that MIP suppressed the levels of the p38 upon in vitro stimulation.

\section{Discussion}

It can be ascertained from these studies that MIP retains its cytotoxic potential even after it is killed, unlike BCG,

Table 2 Cytotoxicity of MIP $\left(3 \times 10^{6}\right.$ cells $\left.\mathrm{ml}^{-1}\right)$ in combination with 5 -FU $(1.562 \mu \mathrm{g}$ to $100 \mu \mathrm{g})$, in pancreatic cancer cells by MTS assay

\begin{tabular}{lllllllll}
\hline & \multicolumn{1}{l}{ 5-FU Concentration $(\mu \mathrm{g})$} \\
\cline { 2 - 8 } & 0 & 1.562 & 3.12 & 6.25 & 12.5 & 25 & 50 & 100 \\
\hline $5-F U$ & 100 & 75 & 48 & 42 & 41 & 40 & 38 & 33 \\
$5-F U+3 \times 10^{6} \mathrm{MIP}$ & 55 & 48 & 36 & 29 & 24 & 21 & 16 & 14 \\
$3 \times 10^{6} \mathrm{MIP}$ & 55 & - & - & - & - & - & - & - \\
\hline
\end{tabular}

Cell proliferation in vitro was plotted as cell survival (\%) at indicated concentrations of these two compounds. Each data point is the average of at least four determinations 


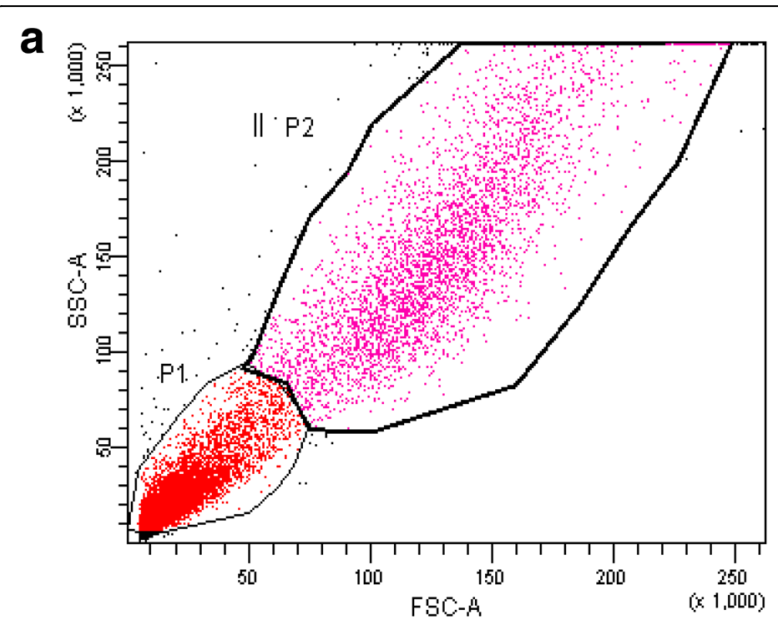

b

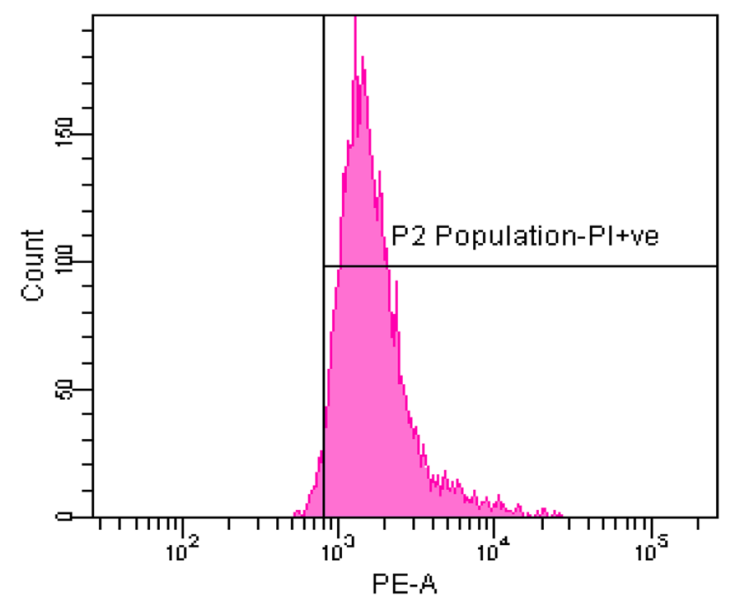

Fig. 2 Apoptosis post MIP treatment. MIP treated Mia-Pa-Ca2 cells were evaluated for apoptosis. Forward scatter was plotted against side scatter where fluorescence from MIP treated was analyzed (a). PI staining of treated Mia-Pa-Ca2 cells (b) Histogram of MIP treated Mia-Pa-Ca2 cells ( $\mathrm{P} 2$ population)

Table 3 Expression of p38, JNK and ERK on treating Mia-Pa-Ca2 cells with MIP $\left(3 \times 10^{6}\right.$ and $1.25 \times 10^{8}$ cells $\left.\mathrm{ml}^{-1}\right)$

\begin{tabular}{lllll}
\hline & \multirow{2}{*}{$\begin{array}{l}\text { MIP Concentration } \\
\text { (cells/ml) }\end{array}$} & \multicolumn{3}{l}{ MAPK expression $(\mathrm{pg} / \mathrm{ml})$} \\
\cline { 3 - 5 } & Untreated cells & 793 & 891 & $88 \mathrm{~h}$ \\
\hline P38 & $1.25 \times 10^{8} \mathrm{MIP}$ & 811 & 730 & 866 \\
& $3.0 \times 10^{6} \mathrm{MIP}$ & 778 & 763 & 723 \\
& Untreated cells & 156 & 180 & 199 \\
JNK & $1.25 \times 10^{8} \mathrm{MIP}$ & 153 & 181 & 200 \\
& $3.0 \times 10^{6} \mathrm{MIP}$ & 139 & 192 & 191 \\
\multirow{3}{*}{ ERK } & Untreated cells & 274 & 256 & 264 \\
& $1.25 \times 10^{8} \mathrm{MIP}$ & 256 & 263 & 258 \\
& $3.0 \times 10^{6} \mathrm{MIP}$ & 266 & 246 & 273 \\
\hline
\end{tabular}

Expression level was plotted as concentration at different time points ( 0 to $48 \mathrm{~h}$ ). Each data point is the average of at least three determinations and has been found to share antigens with Mycobacterium leprae and Mycobacterium tuberculosis. In an experimental model of tuberculosis, MIP immunizations have been shown to be protective [23, 24]. Importantly, MIP immunization in humans has shown prophylactic efficacy against tuberculosis [12].

In cancer studies, MIP is observed to decrease the tumour size in lung cancer and it is also effective against bladder cancer $[25,26]$. Use of MIP as cytotoxic and apoptotic agent on breast adeno-carcinoma cell line MCF-7 and oral cancer cell line ORL-115 has been previously reported [27]. On the other hand, there are no reported effects of MIP on pancreatic cancer even though it remains an aggressive type of neoplasm for which the survival rate is $25 \%$ with multimodality therapy [4]. Our data shows decreased survival of Mia-Pa-Ca2 cells in a dose-dependent manner upon treatment with MIP alone.

Outcome of chemotherapy in pancreatic cancer remains poor. Therefore it is essential to alleviate the toxic effects of treatment and allow the patients to maintain the best possible quality of life. Drugs like gemcitabine and 5-FU remain the standard of care for pancreatic cancer [28], even though it has been almost decades since they were established. Similar to our findings on Mia-Pa-Ca2 cells, previous in-vitro studies reported that treatment of human pancreatic adeno-carcinoma cells (Mia-Pa-Ca2, AsPC-1, Panc-1, and Panc-48) and also of patients with advanced pancreatic cancer with gemcitabine $[29,30]$ and 5-FU $[31,32]$ inhibited cell growth in a dose-dependent manner [33].

Use of combination therapy in pancreatic cancer treatment has a greater chance of success in treating patients [34]. Previous studies show that ID injections of MIP in the deltoid region, together with standard multidrug treatment, increase the clearance of bacilli and reduce the recovery time of leprosy patients [15, 35]. In addition, several side effects of the chemotherapeutic drugs could be reduced with combination therapy. Therefore the present study not only investigated the cytotoxic potential of MIP, but also its efficacy in combination with gemcitabine and 5-FU on Mia-Pa-Ca2 cells. The result obtained suggests that MIP can improve the cytotoxic potential of gemcitabine and 5-FU and ultimately reduce their side effects.

Cells undergoing apoptosis or necrosis have distinct morphological features. It was found by annexin V/PI staining that MIP induced early and late apoptosis in pancreatic cancer cells, but the rate of early apoptosis was significantly higher. Similar results were seen in early apoptosis in pancreatic cell growth by trichostatin A and gemcitabine [36, 37]. Our data reports that MIP suppresses the levels of p38 MAP kinases. Our finding is similar to Patent 20,120,328,574 [38] where MIP and its 
constituents inhibit p38 in Mia-Pa-Ca2 cells by downregulating its level when compared with control cells. Previous studies have also shown that the p38 MAPK inhibitor induced apoptosis in DLD-1 and SW480 which are colon cancer cell lines [39]. Proliferation of p53 mutant and ER-negative breast cancer cells were also inhibited by p38 inhibitors [40]. Further studies are required for evaluating immune response of MIP in a pre-clinical model of pancreatic cancer.

\section{Conclusion}

MIP does not only induce apoptosis, but also could be used to lower the dose of currently used chemotherapeutic drugs against pancreatic cancer. To the best of our knowledge, this is the first study which demonstrates beneficial anti-cancer effect of MIP in pancreatic cancer cells as a p38 MAPK inhibitor. This study suggests that MIP could be of potential benefit for treatment of pancreatic cancer.

\section{Abbreviations}

5- FU: 5-Flurouracil; DMEM: Dulbecco's modified Eagle's Medium; DPBS: Dulbecco's phosphate-buffered saline; ERK: Extracellular signalregulated kinases; FACS: Fluorescence-activated cell sorting; FBS: Fetal bovine serum; FITC: Fluorescein isothiocyanate; IC-50: Half maximal inhibitory concentration; JNK: c-Jun N-terminal kinases; MAPK: Mitogen-activated protein kinase; MIP: Mycobacterium indicus pranii; MTS: (3-(4,5-dimethylthiazol-2-yl)-5-(3carboxymethoxyphenyl)-2-(4-sulfophenyl)-2H-tetrazolium); OD: Optical Density; PI: Propidium lodide

\section{Acknowledgements}

Not applicable.

\section{Funding}

Not applicable.

\section{Availability of data and materials}

Not applicable.

\section{Authors' contributions}

$N D, A D, B K$ and $S R$ have contributed to the conception of the study. RM provided funding and laboratory facilities, AD and ND designed the study. AD performed the experiments. $A D, N D$ and $B K$ have contributed to data analysis. AD and SR have prepared the manuscript. All authors have read and approved the final manuscript.

Ethics approval and consent to participate

Not applicable.

\section{Consent for publication}

Not applicable.

\section{Competing interests}

The authors declare that they have no competing interests.

\section{Publisher's Note}

Springer Nature remains neutral with regard to jurisdictional claims in published maps and institutional affiliations.

\section{Author details}

'Cadila Pharmaceuticals Ltd, 1389, Trasad Road, Dholka, Ahmedabad 382225, India. ${ }^{2}$ Cadila Pharmaceuticals Ltd, Cadila Corporate Campus, Sarkhej-Dholka Road, Bhat, Ahmedabad, Gujarat 382210, India. ${ }^{3}$ Institute of Science, Nirma University, Ahmedabad, Gujarat 382481, India.
Received: 7 April 2017 Accepted: 3 July 2017

Published online: 31 August 2017

\section{References}

1. Ferlay J, Soerjomataram I, Dikshit R, Eser S, Mathers C, Rebelo M, Parkin DM, Forman D, Bray F. Cancer incidence and mortality worldwide: sources, methods and major patterns in GLOBOCAN 2012. Int J Cancer. 2015;136(5): E359-86.

2. Siegel RL, Miller KD, Jemal A. Cancer statistics, 2017. CA Cancer J Clin. 2017:67:7-30

3. Chantrill LA, Nagrial AM, Watson C, et al. Precision medicine for advanced pancreas cancer: the individualized molecular pancreatic cancer therapy (IMPaCT). Trial Clin Cancer Res. 2015;21(9):2029-37.

4. Neoptolemos JP, Stocken DD, Bassi C, et al. Adjuvant chemotherapy with fluorouracil plus Folinic acid vs Gemcitabine following pancreatic cancer resection, a randomized controlled trial. JAMA. 2010;304(10):1073-81.

5. Lee HS, Park SW. Systemic chemotherapy in advanced pancreatic cancer. Gut Liver. 2016;10(3):340-7.

6. Sen P, Gautham A, Manavalan M, Najeeb MA. Bacteria in cancer therapy: an emerging robust strategy. Int Res J Pharm. 2013;4:5.

7. Hamzehzadeh L, Imanparast A, Tajbakhsh A, Rezaee M, Pasdar A. New approaches to use Nanoparticles for treatment of colorectal cancer; a brief review. Nanomed Res J. 2016;1(2):59-68.

8. Hoption Cann SA, van Netten JP, van Netten C. Dr William Coley and tumour regression: a place in history or in the future. Postgrad Med J. 2003;79:672-80.

9. Patyar S, Joshi R, Prasad Byrav DS, Prakash A, Medhi B, Das BK. Review bacteria in cancer therapy: a novel experimental strategy. J Biomed Sci. 2010;17:21.

10. St Jean AT, Zhang M, Forbes NS. Bacterial therapies: completing the cancer treatment toolbox. Curr Opin Biotechnol. 2008;19:511-7.

11. Grange JM, Bottasso O, Stanford CA, Stanford JL. The use of mycobacterial adjuvant-based agents for immunotherapy of cancer. Vaccine. 2008;26: 4984-90.

12. Faujdar J, Gupta P, Natrajan M, Das R, Chauhan DS, Katoch VM, Gupta UD. Mycobacterium Indicus pranii as stand-alone or adjunct immunotherapeutic in treatment of experimental animal tuberculosis. Indian J Med Res. 2011; 134:696-703.

13. Saini V, Raghuvanshi S, Talwar GP, Ahmed N, Khurana JP, Hasnain SE, Tyagi AK, Tyagi AK. Polyphasic taxonomic analysis establishes Mycobacterium Indicus pranii as a distinct species. PLoS One. 2009:4(7):e6263.

14. Talwar GP. Towards development of a vaccine against leprosy: introduction. Lepr India. 1978:50:492-7.

15. Sharma P, Mukherjee R, Talwar GP, et al. Immunoprophylactic effects of the anti-leprosy mw vaccine in household contacts of leprosy patients: clinical field trials with a follow up of 8- 10 years. Lepr Rev. 2005;76:127-43.

16. Kumar P, Tyagi R, Das G, Bhaskar S. Mycobacterium Indicus pranii and Mycobacterium Bovis BCG lead to differential macrophage activation in tolllike receptor-dependent manner. Immunology. 2014;143(2):258-68.

17. Khamar BM, Desai N, Shukla C. Therapeutic vaccine for pancreatic cancer [abstract 1582]. In: Proceedings of the 103rd annual meeting of the American Association for Cancer Research. Chicago: AACR; 2012. Cancer Res. 72(8): Abstract nr 1582

18. Chou TC. Theoretical basis, experimental design, and computerized simulation of synergism and antagonism in drug combination studies. Pharmacol Rev. 2006:58:621-81.

19. Li Y, Sun Y, Jing L, Wang J, Yan Y, Feng Y, Zhang Y, Liu Z, Ma L, Diao A. Lysosome inhibitors enhance the chemotherapeutic activity of doxorubicin in HepG2 cells. Chemotherapy. 2017;62:85-93.

20. Leger DY, Liagre B, Beneytout JL. Low dose leflunomide activates PI3K/Akt signalling in erythroleukemia cells and reduces apoptosis induced by anticancer agents. Apoptosis. 2006;11(10):1747-60.

21. Liagre B, Bertrand J, Leger DY, Beneytout JL. Diosgenin, a plant steroid, induces apoptosis in COX-2 deficient $\mathrm{K} 562$ cells with activation of the p38 MAP kinase signalling and inhibition of NF-KB binding. Int J Mol Med. 2005; 16:1095-101.

22. Vergne-Salle $P$, Leger DY, Bertin $P$, Treves $R$, Beneytout $J$, Liagre $B$. Effects of the active metabolite of leflunomide, A77 1726, on cytokine release and the MAPK signalling pathway in human rheumatoid arthritis synoviocytes. Cytokine. 2005;31:335-48. 
23. Singh IG, Mukherjee R, Talwar GP. Resistance to intravenous inoculation of mycobacterium tuberculosis H37Rv in mice of different inbred strains following immunization with a leprosy vaccine based on mycobacterium $\mathrm{w}$. Vaccine. 1991:9:10-4.

24. Gupta A, Geetha N, Mani J, Upadhyay P, Katoch VM, Natrajan M, Gupta UD, Bhaskar S. Immunogenicity and protective efficacy of "mycobacterium w" against mycobacterium tuberculosis in mice immunized with live versus heatkilled M. W by the aerosol or parenteral route. Infect Immun. 2009;77:223-31.

25. Sur PK, Dastidar AG. Role of mycobacterium w as adjuvant treatment of lung cancer (non-small cell lung cancer). J Indian Med Assoc. 2003;101:118-20.

26. Chaudhuri P, Mukhopadhyay S. Bladder preserving approach for muscle invasive bladder cancer-role of mycobacterium w. J Indian Med Assoc. 2003;101:559-60.

27. Subramaniam M, Lionel LA, Kumar A, Ahmed N, Nagoor NH. Cytotoxic and apoptotic effects of heat killed Mycobacterium Indicus pranii (MIP) on various human cancer cell lines. Sci Rep. 2016;6:19833.

28. Cieslak JA, Strother RK, Rawal M, Du J, Doskey CM, Schroeder SR, Button A, Wagner BA, Buettner GR, Cullen JJ. Manganoporphyrins and Ascorbate enhance Gemcitabine Cytotoxicity in pancreatic cancer. Free Radic Biol Med. 2015;83:227-37.

29. Bold RJ, Chandra J, McConkey DJ. Gemcitabine-induced programmed cell death (apoptosis) of human pancreatic carcinoma is determined by $\mathrm{BCl}-2$ content. Ann Surg Oncol. 1999;6(3):279-85.

30. Cunningham D, Chau I, Stocken DD, Valle JW, Smith D, Steward W, Harper PG, Dunn J, Tudur-Smith C, West J, Falk S, Crellin A, Adab F, Thompson J, Leonard P, Ostrowski J, Eatock M, Scheithauer W, Herrmann R, Neoptolemos JP. Phase III randomized comparison of Gemcitabine versus Gemcitabine plus Capecitabine in patients with advanced pancreatic cancer. J Clin Oncol. 2009;27(33):5513-8.

31. Tonga D, Poot M, Huc D, Oda D. 5-fluorouracil-induced apoptosis in cultured oral cancer cells. Oral Oncol. 2000;36:236-41.

32. Akbari R, Javar HA. Efficacy of Capecitabine and 5- fluorouracil (5-FU) on the human breast cancer cell line (MCF7) - effect of concentration. Am J Res Commun. 2013; 1(6):75-91.

33. Kilani-Jaziri S, Frachet V, Bhouri W, Ghedira K, Chekir-Ghedira L, Ronot X. Flavones inhibit the proliferation of human tumor cancer cell lines by inducing apoptosis. Drug Chem Toxicol. 2012;35(1):1-10.

34. Quinn BA, Lee NA, Kegelman TP, Bhoopathi P, Emdad L, Das SK, Pellecchia M, Sarkar D, Fisher PB. The quest for an effective treatment for an intractable cancer: established and novel therapies for pancreatic Adenocarcinoma. Adv Cancer Res. 2015;127:283-306.

35. Zaheer SA, Mukherjee R, Ramkumar B, Misra RS, Sharma AK, Kar HK, Kaur H, Nair S, Mukherjee A, Talwar GP. Combined multidrug and mycobacterium $w$ vaccine therapy in patients with multibacillary leprosy. J Infect Dis. 1993;167:401-10.

36. Donadelli M, Costanzo C, Beghelli S, Scupoli M, Dandrea M, Bonora A, Piacentini P, Budillon A, Caraglia M, Scarpa A, Palmieri M. Synergistic inhibition of pancreatic adenocarcinoma cell growth by trichostatin a and gemcitabine. Biochim Biophys Acta. 2007;1773:1095-106.

37. Bafna S, Kaur S, Momi N, Batra SK. Pancreatic cancer cells resistance to gemcitabine: the role of MUC4 mucin. Br J Cancer. 2009;101:1155-61.

38. Cadila Pharmaceuticals Ltd., (Modi I, Ghosh PK, Bhardwaj D, Desai N and Khamar B) 2012. P38 INHIBITORS. United State patent application 2012/0328574.

39. Tsuchiya T, Tsuno NH, Asakage M, Yamada J, Yoneyama S, Okaji Y, Sasaki S, Kitayama J, Osada T, Takahashi K, Nagawa H. Apoptosis induction by p38 MAPK inhibitor in human colon cancer cells. Hepato-Gastroenterology. 2008:55(84):930-5.

40. Chen L, Mayer JA, Krisko TI, Speers CW, Wang T, Hilsenbeck SG, Brown PH. Inhibition of the p38 Kinase suppresses the proliferation of human ERnegative breast cancer cells. Cancer Res. 2009;69(23):8853-61.

\section{Submit your next manuscript to BioMed Central and we will help you at every step:}

- We accept pre-submission inquiries

- Our selector tool helps you to find the most relevant journal

- We provide round the clock customer support

- Convenient online submission

- Thorough peer review

- Inclusion in PubMed and all major indexing services

- Maximum visibility for your research

Submit your manuscript at www.biomedcentral.com/submit
Biomed Central 